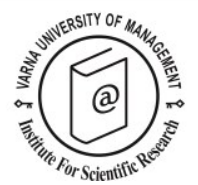

\title{
Weight of criteria in hotel selection: An empirical illustration based on TripAdvisor criteria
}

\author{
Mustafeed Zaman ${ }^{1}$, Laurent Botti ${ }^{1 *}$ and Tan Vo Thanh ${ }^{2}$
}

Received: 09/11/2015 Accepted: 26/11/2015

\footnotetext{
${ }^{1}$ University of Perpignan Via Domitia, 52 Avenue Paul Alduy, Perpignan, France

${ }^{2}$ La Rochelle Business School, France

* Corresponding author: email: Laurent.botti@univ-perp.fr
}

\begin{abstract}
The aim of this paper is to show how to calculate the weight of criteria that influences the decision making process of potential hotel guests. By taking into consideration the growing importance of electronic word-of-mouth and the popularity of hotel reviews websites, this research note exposes the framework to calculate the weight of the 6 TripAdvisor criteria by using the Multi-Criteria Decision Analysis (MCDA) - Analytic Hierarchy Process (AHP) method. 250 tourists in Paris (France) have been interrogated in order to apply the AHP method and to illustrate how to determine the weight of 6 criteria: location, bed quality, comfort \& equipment, service, value for money and, cleanliness. By doing so, this research note facilitates the understanding of AHP method and its application to the hotel sector. The empirical study proposes weight for each criterion by taking into consideration tourists' point of view.
\end{abstract}

(C) 2016 Varna University of Management. All rights reserved

Keywords: AHP Method, Weight of Criteria, Hotel Attributes, Electronic Word-of-Mouth (eWOM), TripAdvisor.

Citation: Zaman, M., L. Botti and T. Vo Thanh (2016) Weight of criteria in hotel selection: An empirical illustration based on TripAdvisor criteria. European Journal of Tourism Research 13, pp. 132-138

\section{Introduction}

Due to the competitive business environment, it is indispensable for hotel managers to understand how potential customers choose their hotel and which criteria have been privileged in their decision-making processes; moreover by considering that Internet has dramatically changed the customer purchasing behaviour (Buhalis \& Law, 2008). According to Nielsen (2013) report, $70 \%$ of customers trust online reviews. So the reviews, widely known as word-of-mouth (WOM), are considered as one of the most influential factors in customer decision-making process.

WOM is defined as a post-purchase oral communication between people where communicator gives non-commercial information on a brand, a service, a product or a company based on his personal experience (Dickinger \& Basu, 1994; Harrison-Walker, 2001). With the development of information 
technology, electronic word-of-mouth (eWOM) (i.e. online reviews, recommendations, rating, etc.) has gained significant importance in decision-making process (Serra-Cantallops \& Salvi, 2014) especially as it is easily accessible to global community via Internet (Litvin et al., 2008). Moreover, users feel free to express themselves in front of a computer rather than being observed (Sun et al., 2006). Therefore, previous studies show that the eWOM influences the decision-making process of potential hotel customers (Mauri \& Minazzi, 2013; Liu \& Zhang, 2014) and according to Gretzel (2007), $77.9 \%$ of TripAdvisor users consulted eWOM for choosing their hotel. In this regard, our research note exposes the framework to calculate the weight of the 6 criteria proposed on TripAdvisor and fills the existing research gap from previous study of Serra-Cantallops \& Salvi (2014).

\section{Weight of criteria in hotel selection}

Criteria play a vital role in different stages of decision-making process (Yavas \& Babakus, 2005). Multiple researches have been done on multi-criteria decision-making process in hotel selection (Chou et al., 2008). Most of them are focused on "Customer's Quality Perception" (Oh, 1999; Albayrak \& Caber, 2015) from a post-experience point of view. Accordingly, they try to understand the contribution of hotel attributes on overall customer satisfaction (Tsaur \& Tzeng, 1996; Chu \& Choi, 2000; Albayrak \& Caber, 2015). Studies show that some attributes are highly important to satisfy the customers while others play insignificant roles. On the contrary, very few researches have been focused on the weight of attributes that play a vital role in customer decisionmaking process. TripAdvisor proposes 6 attributes which are subject to customers' evaluation during their stay in the respective hotel: location, bed quality, comfort \& equipment, service, value for money and, cleanliness. While a potential customer searches for a hotel on TripAdvisor, he or she goes through the eWOM based on his or her own criteria, which are subjective (Figure 1). According to Crouch (2011), the decision making process is based on an array of information connecting multiple criteria. SerraCantallops and Salvi (2014) mentioned the necessity of calculating the weight of these criteria. Therefore, the research gap on the

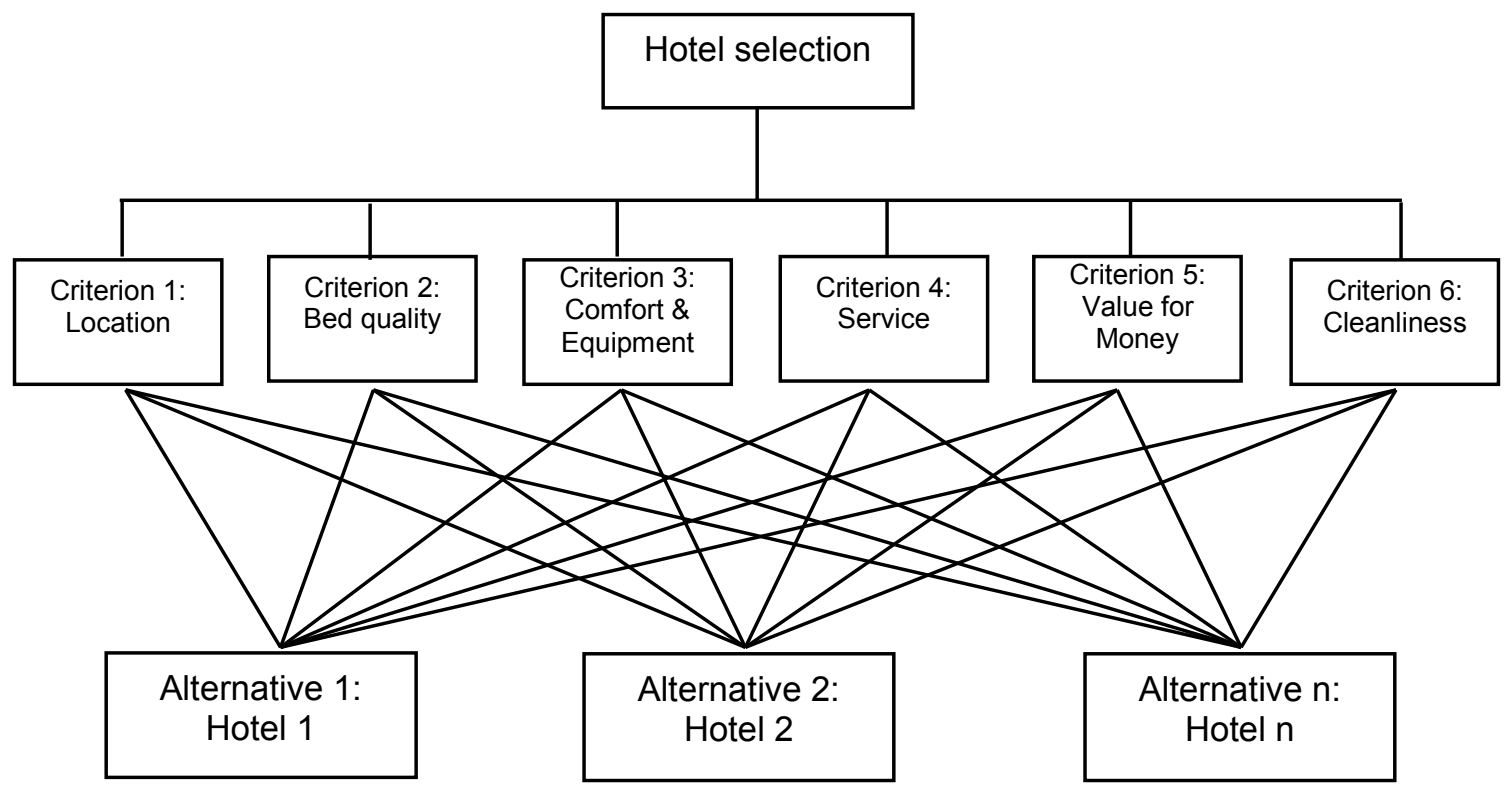

Figure 1. Decision-Making Process on Hotel Selection (developed from Crouch (2011: 32) and based on TripAdvisor criteria). 
Table 1. Performance Matrix

\begin{tabular}{ccccc} 
& & \multicolumn{3}{c}{ Decision-making criteria (C) } \\
\cline { 3 - 5 } & & $\mathrm{C}_{1}$ & $\ldots$ & $\mathrm{C}_{\mathrm{m}}$ \\
\hline \multirow{3}{*}{ Alternatives (A) } & $\mathrm{A}_{1}$ & $\mathrm{R}_{11}$ & $\ldots$ & $\mathrm{R}_{1 \mathrm{~m}}$ \\
& $\ldots$ & $\ldots$ & $\ldots$ & $\ldots$ \\
& $\mathrm{A}_{\mathrm{n}}$ & $\mathrm{R}_{\mathrm{n} 1}$ & $\ldots$ & $\mathrm{R}_{\mathrm{nm}}$ \\
\hline Weight $(\mathrm{W})$ & & $\mathrm{W}_{1}$ & $\ldots$ & $\mathrm{W}_{\mathrm{m}}$ \\
\hline
\end{tabular}

Table 2. Insight of Saaty Scale

\begin{tabular}{lcc}
\hline Verbal Appreciation & Numeric Rating & Reciprocal Value \\
\hline Extreme importance & 9 & $1 / 9$ \\
Very, very strong & 8 & $1 / 8$ \\
Very strong & 7 & $1 / 7$ \\
Strong plus & 6 & $1 / 6$ \\
Strong importance & 5 & $1 / 5$ \\
Moderate plus & 4 & $1 / 4$ \\
Moderate importance & 3 & $1 / 3$ \\
Weak & 2 & $1 / 2$ \\
Equal importance & 1 & 1 \\
\hline
\end{tabular}

weight of criteria in hotel selection based on eWOM has been identified but still remained untouched.

The decision-maker needs to evaluate and decide on $n$ alternatives represented by the vector $A$ : $(A i ; i=1,2,3, \ldots n)$, which could be analysed by $m$ criteria represented by the vector $C:(C j ; j=1,2,3, \ldots, m)$. The weight of criteria varies from person to person and it could be represented by the vector $W:(W j ; j=$ $1,2,3, \ldots, m)$. The assessment of each of the alternatives $i$ on each of the criteria $j$ gives the results Rij as presented in Table 1.

\section{Analytic Hierarchy Process (AHP) and the weight of criteria}

AHP method has been developed by Saaty $(1977,1980)$ and it is very useful when the decision maker is unable to construct a utility function (Ishizaka \& Nemery, 2013). In this regard, pair-wise comparison of criteria is a solution. The decision maker gives a relative verbal appreciation between two criteria rather than a numerical judgement.

If two criteria $C_{h}$ and $C_{k}$ are compared, $e_{h k}$ indicates the evaluation of the criterion $C_{h}$ relatively to the criterion $C_{k}$. The pair-wise comparison matrix $A$ is composed of all the relative evaluations by considering that $e_{h k}=1 /$ $e_{k h}$.

By taking into consideration the Eigen-Value formulation,

(1) Aw $=m w$

where $w=\left(w_{1}, w_{2} \ldots, w_{m}\right)$ and $m w$ could be obtained as follow:

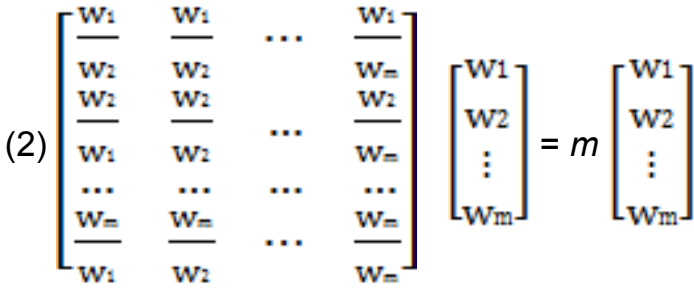

Since the observed matrix $A$ might not be consistent, the estimation of $w$ could be calculated as follow (where $\kappa_{\max }$ represents the maximum Eigen-Value of matrix $A$ ):

(3) Aw $=\swarrow_{\max } \mathrm{w}$

The value of the $\kappa_{\max }$ could be estimated by normalizing the element of in each column. In order to measure the inconsistency $(A$ is consistent if $\kappa_{\max }=m$ and we always have the 
$\kappa_{\max }-m$ ), consistency ratio (C.R.) could be calculated by using the following steps:

(4) Consistency Index (C.I.) $=(\swarrow \max -\mathrm{m}) /(\mathrm{m}-1)$

Therefore, (5) C.R. = C.I. / R.I.

C.R. should be less or equal to 0.1 in order to get the result acceptable. The C.I. of a randomly generated pair-wise comparison matrix (Saaty, 1980) and $m=$ order of matrix.

\section{An empirical illustration based on Parisian tourists}

AHP method is applied. The data was collected from 250 tourists in Paris during 2015 summer, aged between 30 to 65 years, travelling for leisure purpose and used to stay in 3 to 5 stars hotels while travelling and, needless to say, choosing their hotels on TripAdvisor. By taking into consideration TripAdvisor guests' satisfaction attributes, we consider the 6 criteria: $c_{1}=$ location of the hotel, $c_{2}=$ bed/sleep quality, $c_{3}=$ comfort $\&$ equipment, $c_{4}$ $=$ service/personnel, $c_{5}=$ value for money and, $c_{6}=$ cleanliness .

In order to calculate the weight of each criterion for potential customers by AHP method, we conducted a pair-wise comparison between these 6 criteria by questioning 250 tourists in strategic tourist spots and some 4 star hotels in Paris (cf. survey copy in Appendix 1). The interviewees confirmed that they always consulted eWOM on TripAdvisor before making any purchase.

In Table 4, a pair-wise comparison matrix has been done which is an example for one particular tourist interrogated in Paris (31 years old, leisure traveller). In order to rapidly evaluate the weight of criteria for each questionnaire, at first, we completed the upper triangular matrix (in bold letters) by using the value from the Table 2. Then, lower triangular matrix was completed by the reciprocal values of the upper triangular matrix.

The next step consists of normalisation of the matrix. Therefore, we got the weight of each criterion from the average of each line. C.R. = 0.1 which means that the result is acceptable.

Thus, 250 questionnaires have been calculated individually and the average result shows that the cleanliness has the highest value, which affirms Ryan \& Huimin's (2007) study. However, Albayrak \& Caber (2015) found that

Table 3. Random indices from Saaty (1977)

\begin{tabular}{lllllllllll}
\hline $\mathbf{m}$ & $\mathbf{1}$ & $\mathbf{2}$ & $\mathbf{3}$ & $\mathbf{4}$ & $\mathbf{5}$ & $\mathbf{6}$ & $\mathbf{7}$ & $\mathbf{8}$ & $\mathbf{9}$ & $\mathbf{1 0}$ \\
\hline R.I. & 0.00 & 0.00 & 0.58 & 0.90 & 1.12 & 1.24 & 1.32 & 1.41 & 1.46 & 1.49 \\
\hline
\end{tabular}

Table 4. Pair-wise comparison matrix (example of a tourist)

\begin{tabular}{ccccccc}
\hline Criteria & $\mathrm{C}_{1}$ & $\mathrm{C}_{2}$ & $\mathrm{C}_{3}$ & $\mathrm{C}_{4}$ & $\mathrm{C}_{5}$ & $\mathrm{C}_{6}$ \\
\hline $\mathrm{C}_{1}$ & 1 & $1 / 2$ & $\mathbf{1 / 2}$ & $\mathbf{2}$ & $\mathbf{1}$ & $\mathbf{1 / 2}$ \\
$\mathrm{C}_{2}$ & 2 & 1 & 1 & 2 & 2 & $1 / 3$ \\
$\mathrm{C}_{3}$ & 2 & 1 & 1 & 2 & 2 & $1 / 2$ \\
$\mathrm{C}_{4}$ & $1 / 2$ & $1 / 2$ & $1 / 2$ & 1 & $1 / 3$ & $1 / 6$ \\
$\mathrm{C}_{5}$ & 1 & $1 / 2$ & $1 / 2$ & 3 & 1 & $1 / 12$ \\
$\mathrm{C}_{6}$ & 2 & 3 & 2 & 6 & 2 & 1 \\
\hline Total & $\mathbf{8 . 5 0}$ & $\mathbf{6 . 5 0}$ & $\mathbf{5 . 5 0}$ & $\mathbf{1 6 . 0 0}$ & $\mathbf{8 . 3 3}$ & $\mathbf{3 . 0 0}$ \\
\hline
\end{tabular}

Table 5. Normalisation of matrix (example of a tourist)

\begin{tabular}{ccccccccc}
\hline Criteria & $\mathbf{C}_{1}$ & $\mathbf{C}_{\mathbf{2}}$ & $\mathbf{C}_{3}$ & $\mathbf{C}_{\mathbf{4}}$ & $\mathbf{C}_{5}$ & $\mathbf{C}_{6}$ & Total & Weight of criteria \\
\hline $\mathbf{C}_{1}$ & 0.12 & 0.08 & 0.09 & 0.13 & 0.12 & 0.17 & 0.70 & 0.12 \\
$\mathbf{C}_{\mathbf{2}}$ & 0.24 & 0.15 & 0.18 & 0.13 & 0.24 & 0.11 & 1.05 & 0.17 \\
$\mathbf{C}_{3}$ & 0.24 & 0.15 & 0.18 & 0.13 & 0.24 & 0.17 & 1.10 & 0.18 \\
$\mathbf{C}_{4}$ & 0.06 & 0.08 & 0.09 & 0.06 & 0.04 & 0.06 & 0.38 & 0.06 \\
$\mathbf{C}_{5}$ & 0.12 & 0.08 & 0.09 & 0.19 & 0.12 & 0.17 & 0.76 & 0.13 \\
$\mathbf{C}_{6}$ & 0.24 & 0.46 & 0.36 & 0.38 & 0.24 & 0.33 & 2,01 & 0.33 \\
\hline Total & $\mathbf{1 . 0 0}$ & $\mathbf{1 . 0 0}$ & $\mathbf{1 . 0 0}$ & $\mathbf{1 . 0 0}$ & $\mathbf{1 . 0 0}$ & $\mathbf{1 . 0 0}$ & - & $\mathbf{1 . 0 0}$ \\
\hline
\end{tabular}


Table 6. Weight of criteria according to duration of stay

\begin{tabular}{lcc} 
& Less than 3 night stay & More than 3 night stay \\
\hline Location $\left(\mathrm{C}_{1}\right)$ & 0.24 & 0.09 \\
Sleep Quality $\left(\mathrm{C}_{2}\right)$ & 0.12 & 0.19 \\
Comfort and Equipment $\left(\mathrm{C}_{3}\right)$ & 0.07 & 0.15 \\
Service $\left(\mathrm{C}_{4}\right)$ & 0.10 & 0.11 \\
Value for Money $\left(\mathrm{C}_{5}\right)$ & 0.22 & 0.17 \\
Cleanliness $\left(\mathrm{C}_{6}\right)$ & 0.25 & 0.29 \\
\hline
\end{tabular}

Table 7. Weight of criteria according to income

\begin{tabular}{lcc} 
& $\begin{array}{c}\text { Annual income less than 25000 } \\
\text { US dollar }\end{array}$ & $\begin{array}{c}\text { Annual income more than } 25000 \text { US } \\
\text { dollar }\end{array}$ \\
\hline Location $\left(\mathrm{C}_{1}\right)$ & 0.16 & 0.20 \\
Sleep Quality $\left(\mathrm{C}_{2}\right)$ & 0.11 & 0.18 \\
Comfort and Equipment $\left(\mathrm{C}_{3}\right)$ & 0.07 & 0.14 \\
Service $\left(\mathrm{C}_{4}\right)$ & 0.08 & 0.14 \\
Value for Money $\left(\mathrm{C}_{5}\right)$ & 0.34 & 0.07 \\
Cleanliness $\left(\mathrm{C}_{6}\right)$ & 0.24 & 0.27 \\
\hline
\end{tabular}

the overall cleanliness had a lower importance. The value for money was the second important criterion followed by the location. Comfort \& service have lower importance however; Ryan and Saleh (1992) found that they were subject to duration of stay.

Among the 250 tourists, $69 \%$ stayed less than 3 nights and therefore, result shows that the weight of sleep quality and, comfort and equipment increases by the duration of stay.

Interviewees, who earn more than 25000 US dollar annually (36\% of respondents), look for better location, comforts and additional services.

The weight of criteria not only fills the previous research gap (Serra-Cantallops \& Salvi, 2014) but also gives an insight on eWOM of Trip Advisor for hoteliers in order to adopt the "bestpractice".

\section{Conclusion, limits and perspectives}

This research note shows how MCDA-AHP method can be used for calculating the weight of criteria. It is the first research note that measures the weight of criteria of eWOM of TripAdvisor from a potential customers' perspective. AHP method could be used to evaluate others decision-making criteria in order to anticipate the need and desire of international tourists. One of the limitations of this research note is that the sample is based on only 250 respondents. Further studies could be focused on more detailed information such as business vs. leisure traveller, tourists' country of origin, socio-demographic situations, etc.

\section{References}

Albayrak, T., \& Caber, M. (2015). Prioritisation of the hotel attributes according to their influence on satisfaction: A comparison of two techniques. Tourism Management, 46, 43-50.

Buhalis, D., \& Law, R. (2008). Progress in information technology and tourism management: 20 years on and 10 years after the Internet-the state of eTourism research. Tourism Management, 29 (4), 609-623.

Chou, T-Y., Hsu, C-L., \& Chen, M-C. (2008). A fuzzy multi-criteria decision model for international tourist hotels location selection. International Journal of Hospitality Management, 27(2), 293-301.

Chu, R.K.S., \& Choi, T. (2000). An importantperformance of hotel selection factors in Hong Kong hotel industry: a comparison of business and leisure travellers. Tourism Management, 21(4), 363-377.

Crouch, G.I. (2011). Destination Competitiveness: An Analysis of Determinant Attributes. Journal of Travel Research, 50(I), 27-45.

DGE (2014). Chiffres Clés du Tourisme. URL: http://www.entreprises.gouv.fr/etudes-et- 
statistiques/chiffres-cles-tourisme (Accessed on 01.08.2015)

Dickinger, A. S., \& Basu, K. (1994). Customer loyalty: Toward an integrated conceptual framework. Journal of the Academy of Marketing Science, 22(2), 99-113.

Gretzel, U. (2007). Online Travel Review Study: Role and Impact of Online Travel Reviews. Texas A\&M University, Laboratory for Intelligent Systems in Tourism, College Station.

Harrison-Wallker, L.J. (2001). The measurement of word of mouth communication and an investigation of service quality and customer commitment as potential antecedents. Journal of Service Research, 4(1), 60-75.

Ishizaka, A., \& Nemery, P. (2013). Multi-Criteria Decision Making Analysis -Methods and Software. John Wiley \& Sons Ltd. UK.

Litvin, S.W., Goldsmith, R.E., \& Pan, B. (2008). Electronic word-of-mouth in hospitality and tourism management. Tourism Management, 29(3), 458-468.

Liu, J.N.K., \& Zhang, E.Y. (2014). An investigation of factors affecting customer selection of online hotel booking channels. International Journal of Hospitality Management, 39, 71-83.

Mauri, A.G., \& Minazzi, R., (2013). Web reviews influence on expectations and purchasing intentions of hotel potential customers. International Journal of Hospitality Management, 34, 99-107.

Nielsen (2013). Global Trust in Advertising \& Brand Message. The Nielsen Company, New York, USA.

Oh, H., (1999). Service quality, customer satisfaction, and customer value: a holistic perspective. International Journal of Hospitality Management, 18(1), 67-82.
Ryan, C., \& Huimin, G. (2007). Perceptions of Chinese hotels. Cornell Hotel \& Restaurant Administration Quarterly, 48(4), 380-391.

Ryan, C., \& Saleh, F. (1992). Client perceptions of hotels: A multi-attribute approach. Tourism Management, 13(2), 163-168.

Saaty, T. (1977). A scaling method for priorities in hierarchical structures. Journal of Mathematical Psychology, 15(3), 234-281.

Saaty, T., 1980. The Analytics Hierarchy Process, McGraw-Hill, New York.

Serra-Cantallops, A., \& Salvi, F. (2014). New consumer behavior: A review of research on eWOM and hotels. International Journal of Hospitality Management, 36, 41-51.

Sun, T., Youn, S., Wu, G., \& Kuntaraporn, M. (2006). Online word-of-mouth (or mouse): an exploration of its antecedents and consequences. Journal of ComputerMediated Communication, 11(4), 11041127.

Tsaur, S.H., \& Tzeng, G.H. (1996). Multiattribute Decision Making Analysis for Customer Preference of Tourist Hotels. Journal of Travel \& Tourism Marketing, 4(4), 55-69.

Yavas, U., \& Babakus, E. (2005). Dimensions of hotel choice criteria: congruence between business and leisure travelers. International Journal of Hospitality Management, 24(3), 359-367. 


\begin{tabular}{|c|c|c|c|c|c|c|c|c|c|c|c|c|c|c|c|}
\hline $\begin{array}{c}\infty \\
\text { E⿱ } \\
\frac{0}{0} \\
\end{array}$ & 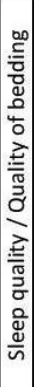 & 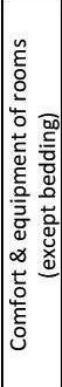 & 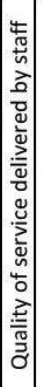 & 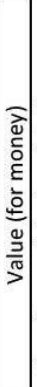 & 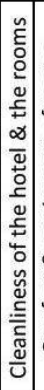 & 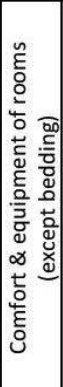 & 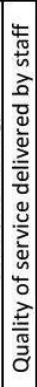 & 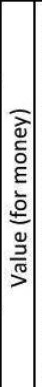 & 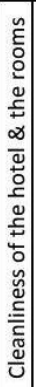 & 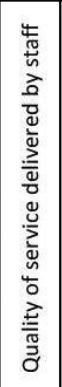 & 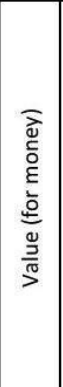 & 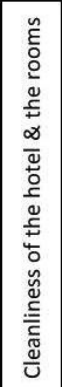 & 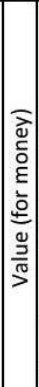 & 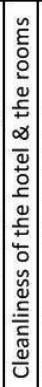 & 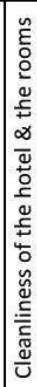 \\
\hline әэuеนоdu! әшәגіх $\exists$ & $a$ & $a$ & a) & a) & a) & $a$ & a & a) & a & $a$ & $\sigma$ & $a$ & a & a) & a \\
\hline 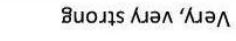 & $\infty$ & $\infty$ & $\infty$ & $\infty$ & $\infty$ & $\infty$ & $\infty$ & $\infty$ & $\infty$ & $\infty$ & $\infty$ & $\infty$ & $\infty$ & $\infty$ & $\infty$ \\
\hline Suodzs Nuə^ & $n$ & $n$ & $n$ & $n$ & $n$ & n & $n$ & $n$ & n & $\wedge$ & $r$ & $\wedge$ & $\wedge$ & $n$ & $r$ \\
\hline snjd suodts & 6 & $\bullet$ & 0 & 6 & 6 & 6 & 6 & 6 & 6 & 6 & 6 & 6 & 6 & 6 & 6 \\
\hline әJueนrodu! suodts & in & in & in & in & in & in & in & in & in & in & in & in & in & in & in \\
\hline sn|d әтеләроW & A & 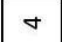 & $\nabla$ & $\nabla$ & $\nabla$ & $\nabla$ & $\theta$ & + & $\theta$ & $\nabla$ & $\theta$ & $\theta$ & $\theta$ & + & H \\
\hline әэиедодш! әңедәро & $m$ & $m$ & $m$ & $m$ & $m$ & $m$ & $m$ & $m$ & $m$ & $m$ & $m$ & $m$ & $m$ & $m$ & $m$ \\
\hline уеәм & $\sim$ & N & $\sim$ & $\sim$ & $\sim$ & N & $\sim$ & $\sim$ & $\sim$ & N & N & N & $\sim$ & $\sim$ & a \\
\hline әэие_. & -1 & $\rightarrow$ & -1 & -1 & -1 & $\rightarrow$ & -1 & -1 & -1 & $\rightarrow$ & $\rightarrow$ & -1 & -1 & -1 & -1 \\
\hline уеәм & $\sim$ & $\sim$ & $\sim$ & $\sim$ & $\sim$ & N & $\sim$ & $N$ & $\sim$ & N & N & n & $\sim$ & $\sim$ & $\sim$ \\
\hline әэиедорищ әүедәроW & $m$ & $m$ & $m$ & $m$ & $m$ & $m$ & $m$ & $m$ & $m$ & $m$ & $m$ & $m$ & $m$ & $m$ & $m$ \\
\hline sn|d әғеләроW & A & $\nabla$ & + & $\checkmark$ & + & $\theta$ & $\theta$ & + & $\checkmark$ & $\theta$ & $\nabla$ & $\nabla$ & $\theta$ & + & $\theta$ \\
\hline әэueนodm! suodts & in & in & in & in & in & in & in & in & in & n & in & in & in & in & n \\
\hline snjd suoxts & 6 & $\bullet$ & 0 & 6 & 6 & $\bullet$ & 6 & 6 & 6 & 6 & 6 & 6 & 6 & 6 & 6 \\
\hline Suodis Nà & r & r & $\wedge$ & $\wedge$ & $n$ & r & $n$ & $N$ & 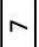 & n & n & r & $\wedge$ & $n$ & $r$ \\
\hline 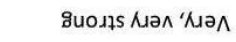 & $\infty$ & $\infty$ & $\infty$ & $\infty$ & $\infty$ & $\infty$ & $\infty$ & $\infty$ & $\infty$ & $\infty$ & $\infty$ & $\infty$ & $\infty$ & $\infty$ & $\infty$ \\
\hline әәиеนdш! әшәдұх $\exists$ & $\sigma$ & $a$ & a & a) & a & $a$ & $a$ & $a$ & a & $a$ & $a$ & $a$ & a & a & a \\
\hline $\begin{array}{l}\frac{}{c} \\
\frac{\mathfrak{g}}{\mathrm{g}} \\
\frac{3}{\mathrm{~J}}\end{array}$ & 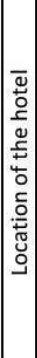 & 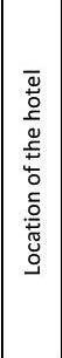 & 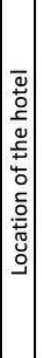 & 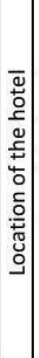 & 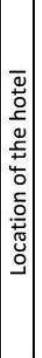 & 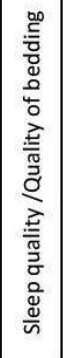 & 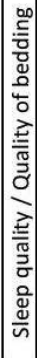 & 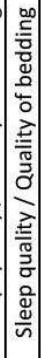 & 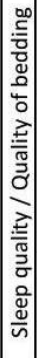 & 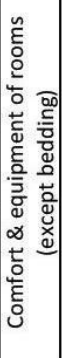 & 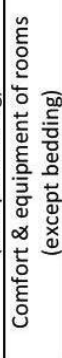 & 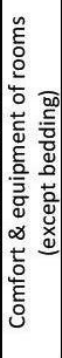 & 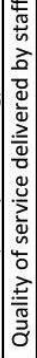 & 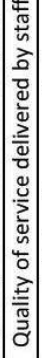 & 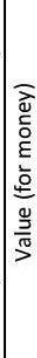 \\
\hline
\end{tabular}

